Case Reports
in Dermatology
Case Rep Dermatol 2021;13:75-82

DOI: 10.1159/000511692

Published online: February 1, 2021
(C) 2021 The Author(s)

Published by S. Karger AG, Basel

www.karger.com/cde

This article is licensed under the Creative Commons Attribution-NonCommercial 4.0 International License (CC BY-NC) (http://www.karger.com/Services/OpenAccessLicense). Usage and distribution for commercial purposes requires written permission.

\title{
Squamous Cell Carcinoma within a Congenital Nevus Sebaceous: Case Report and Literature Review
}

\author{
Petchlada Achavanuntakul Kanchalit Thanomkitti \\ Department of Dermatology, Faculty of Medicine Siriraj Hospital, Mahidol University, \\ Bangkok, Thailand
}

\section{Keywords}

Nevus sebaceous · Squamous cell carcinoma · Malignant neoplasm

\begin{abstract}
Nevus sebaceous (NS) is a benign hamartoma that typically occurs on the head and neck area at birth. Occasionally, secondary neoplasms can develop on top of the original nevus, which usually occur in the middle age. Squamous cell carcinoma (SCC) arising in NS may occur but is very rare. We report the case of a 44-year-old female with an asymptomatic erythematous papule arising within a hairless yellowish plaque on the left parietal area of her scalp for a month. An excisional biopsy was done, and the histopathologic examination revealed SCC arising in the NS.

\author{
(C) 2021 The Author(s)
}

Published by S. Karger AG, Basel
\end{abstract}

\section{Introduction}

Nevus sebaceous (NS), a variant of an epidermal nevus, is a benign congenital hamartoma first described by Josef Jadassohn in 1895. It typically occurs on the head and neck area as a round or linear, yellowish, hairless plaque along the line of Blaschko [1]. There are three stages of the disease. The initial stage occurs in infancy and childhood when there is an underdevelopment of the hair and sebaceous glands. The second stage develops when the patient

Kanchalit Thanomkitti
Department of Dermatology
Faculty of Medicine Siriraj Hospital, Mahidol University
2 Wanglang Road, Bangkoknoi, Bangkok 10700 (Thailand)
kanchalitt@gmail.com




\section{Case Reports in Dermatology}

Case Rep Dermatol 2021;13:75-82

DOI: 10.1159/000511692

(C) 2021 The Author(s). Published by S. Karger AG, Basel www.karger.com/cde

Achavanuntakul and Thanomkitti: Squamous Cell Carcinoma within a Congenital Nevus Sebaceous: Case Report and Literature Review

enters puberty. At this stage, there are epidermal hyperplasia, massive development of sebaceous glands, and maturation of the apocrine glands. The final stage might develop in middle adulthood. It is characterized by the growth of benign or malignant neoplasms on top of the original nevus [2]. The first and second most common secondary neoplasms are benign tumors - trichoblastoma and syringocystadenoma papilliferum (SCAP), respectively. Among malignant neoplasms, basal cell carcinoma (BCC) is the most common, while squamous cell carcinoma (SCC) is rarely found to arise within the NS [3]. We report herein a case of SCC arising in a NS, along with a review of the literature.

\section{Case Report}

A 44-year-old Thai female presented with an asymptomatic erythematous papule arising within a hairless, yellowish plaque on the left parietal area of her scalp, which she had had for a month. The yellowish plaque was noticed since birth and had gradually increased in size. She denied any underlying disease and any history of trauma. There was no family history of similar skin lesions.

On physical examination, a solitary erythematous papule, size $0.3 \mathrm{~cm}$ in diameter, within a well-defined, hairless, verrucous, yellowish plaque, size $1.5 \times 3 \mathrm{~cm}$, was found on the left parietal area of her scalp (Fig. 1). There was no regional lymphadenopathy.

To minimize the length of the surgical scar, the arising tumor was widely excised, along with some surrounding yellowish plaque. A histopathologic examination showed focally keratinizing, atypical, squamous epithelial cells arising from the epidermis and extending into the dermis. The tumor cells were large and composed of eosinophilic, focally glassy cytoplasm, and vesicular nuclei. Horn pearls and individual cell keratinization were also present. The adjacent skin of the tumor showed acanthosis and papillomatosis, with the abnormal feature of sebaceous glands which opened directly to the skin surface. Many ectopic apocrine glands associated with lacking anagen hair were observed (Fig. 2). Finally, the patient was diagnosed with SCC arising in the NS.

The patient did not show any evidence of superficial lymphadenopathy or metastasis, including showing a normal chest radiography. Eight months later, further excision of the residual NS was made. Histopathologic examination found no residual SCC or other secondary neoplasms. To date, the patient has had no tumor recurrence.

\section{Discussion}

NS is a benign congenital nevus found in only $0.3 \%$ of newborns [4]. It usually presents as an asymptomatic, linear or oval, velvety, verrucous plaque with variable attributes of color and size. The common locations of NS are the face and scalp, where hair loss may be observed as an additional feature. Histological findings typically reveal papillomatous hyperplasia of the epidermis with hypergranulosis and hyperkeratosis; underdeveloped hair follicles; and ectopic apocrine glands. The sebaceous glands are initially hypoplastic and superficially located. 


\section{Case Reports in Dermatology}

Case Rep Dermatol 2021;13:75-82

DOI: $10.1159 / 000511692$

(C) 2021 The Author(s). Published by S. Karger AG, Basel www.karger.com/cde

Achavanuntakul and Thanomkitti: Squamous Cell Carcinoma within a Congenital Nevus Sebaceous: Case Report and Literature Review

They are well developed and mature gradually as the patient ages [2]. Most of the patients noticed progressive enlargement and thickening of the lesion during puberty, while secondary neoplasms are generally found in adulthood, particularly during the fifth and sixth decades [3].

The most common benign neoplasm is trichoblastoma, followed by SCAP. Various types of benign neoplasms can be found arising in the NS, including apocrine/eccrine adenoma, trichilemmoma, sebaceoma, syringoma, hidradenoma, seborrheic keratosis, and melanocytic nevi. A malignant transformation may also present in the NS, but only rarely. BCC is the most frequently occurring malignant neoplasm. The remainder are SCC, sebaceous carcinoma, apocrine carcinoma, and microcystic adnexal carcinoma [3, 5]. In a large retrospective analysis of NS published in 2014, the incidence of secondary proliferations was $22.5 \%$. Of these, $2.5 \%$ were malignant neoplasms, and only four SCCs ( $0.57 \%$ ) were found [3]. Until now, there have been a small number of cases with secondary SCC in the NS, as identified in 20 case reports and case series in English [2, 3, 5-22].

The characteristics of the reported cases of SCC occurring in the NS are shown in Table 1. The prevalence of SCC arising in the NS was approximately equal in both sexes. It usually occurred in middle adulthood, as in the case of our patient. However, the youngest case was reported in a 2.5-year-old girl who had a rapidly growing hard wart on her congenital NS for 3 weeks [6]. Later, the case was reviewed. From the clinical and histological appearance, the diagnosis of SCC was called into question, thus making the case of a 9-year-old girl to possibly be the earliest one [7].

The onset of a newly developing lesion being diagnosed with SCC in NS ranged from 2 weeks to 5 years. However, the majority had a timing of onset of less than 6 months. Regarding the size of SCC, $60 \%$ of the documented lesions had a diameter of only $1 \mathrm{~cm}$ or less. Meanwhile, one-third of the SCC lesions larger than $3 \mathrm{~cm}$ were found to be associated with local invasion and distant metastasis. The common locations of SCC arising in the NS were also the face and scalp. An atypical location was observed on the trunk of two patients. The first case was a 52year-old male with an ulcerated, cauliflower-like growth on a chronic plaque-like lesion on his right scapula, regarding which a histological examination showed a collision of SCC, SCAP, and apocrine adenoma arising in the NS [8]. Another case was a 51-year-old male who had a linear NS with arising SCC on the right side of his trunk [9].

There were five cases of collision tumors of SCC and other neoplasms which had developed in the NS. The majority of them (three patients) were diagnosed with a collision tumor of SCC and BCC reported from 1970 to 2008 [10-12]. As for the rest, one was a patient who presented with a collision of SCC, SCAP, and apocrine adenoma (mentioned before), and another was an 11-year-old girl diagnosed with two SCCs and incidental SCAP within the NS on the vertex of her scalp $[8,13]$. Furthermore, Turan et al. [14] reported a male patient who had two SCCs developed in different locations of the NS.

In terms of metastasis, there were two male cases reported in the English literature and another male case reported in the non-English literature $[10,12,15]$. Each of them was diagnosed with SCC arising in NS with a very aggressive clinical course in their middle adulthood, with their ages ranging from 42 to 55 years. Moreover, one patient had a collision of SCC and BCC. Regional lymph node and lung were the two most common metastatic organs. Massive 


\section{Case Reports in Dermatology}

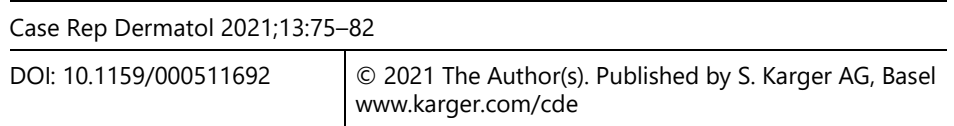

Achavanuntakul and Thanomkitti: Squamous Cell Carcinoma within a Congenital Nevus Sebaceous: Case Report and Literature Review

local invasion to the frontal bone and dura mater was reported by Domingo and Helwig [15]. Two cases, reported in the English literature, similarly presented with rapidly progressive lesions on the face and in the scalp region, larger than $3 \mathrm{~cm}$ in diameter; multiple recurrences of tumors occurred after treatment with combined surgical excision and radiotherapy, but ultimately the patients died within 15 months after their first diagnosis $[12,15]$. Therefore, physicians should be cautious when observing a sudden evolution of a lesion arising in NS. Early histopathological examination and then evaluation of local invasion and metastasis are recommended.

In general, various dermatological procedures can be used to treat NS, such as surgical excision with or without skin graft, cryosurgery, dermabrasion, photodynamic therapy, and ablative lasers (e.g., carbon dioxide laser, erbium laser) [23, 24]. However, the efficacy of eliminating all components of NS and preventing a malignant transformation is uncertain in some cases. So, the current recommendation in the management of NS is prophylactic excision when individual patients can tolerate the procedure or when there may be follow-up difficulties [3, 7]. But when a malignant neoplasm develops, the treatment options for primary tumors are Mohs micrographic surgery or wide excision [17]. As previously reported, most of the patients had no evidence of tumor recurrence after treatment with surgical excision.

In conclusion, our patient was a case of SCC, a rare secondary neoplasm, arising in the NS. The malignant tumor was widely excised with a free surgical margin. Later, prophylactic excision of the remaining NS was performed after the scar matured.

\section{Acknowledgement}

The authors are grateful to Dr. Manasmon Chairatchaneeboon of Dermatopathology Unit, Dermatology Department, Faculty of Medicine Siriraj Hospital, Mahidol University for assistance in histopathological evaluation.

\section{Statement of Ethics}

The patient gave her informed consent for publication of this case report and any accompanying images. The study was conducted ethically in accordance with the World Medical Association Declaration of Helsinki.

\section{Conflict of Interest Statement}

The authors declare no conflicts of interest.

\section{Karger'=}




\section{Case Reports in Dermatology}

Achavanuntakul and Thanomkitti: Squamous Cell Carcinoma within a Congenital Nevus Sebaceous: Case Report and Literature Review

\section{Funding Sources}

This was an unfunded study.

\section{Author Contributions}

P.A. carried out the data collection and writing of the manuscript. K.T. participated in the manuscript revision and acted as the corresponding author. All authors read and approved the final manuscript.

\section{References}

1 Patel P, Malik K, Khachemoune A. Sebaceus and Becker's nevus: overview of their presentation, pathogenesis, associations, and treatment. Am J Clin Dermatol. 2015 Jun;16(3):197-204.

2 Mehregan AH, Pinkus H. Life history of organoid nevi. Special reference to nevus sebaceus of jadassohn. Arch Dermatol. 1965 Jun;91(6):574-88.

3 Idriss MH, Elston DM. Secondary neoplasms associated with nevus sebaceus of Jadassohn: a study of 707 cases. J Am Acad Dermatol. 2014 Feb;70(2):332-7.

4 Alper JC, Holmes LB. The incidence and significance of birthmarks in a cohort of 4,641 newborns. Pediatr Dermatol. 1983 Jul;1(1):58-68.

5 Aguayo R, Pallarés J, Casanova JM, Baradad M, Sanmartín V, Moreno S, et al. Squamous cell carcinoma developing in Jadassohn's sebaceous nevus: case report and review of the literature. Dermatol Surg. 2010 Nov;36(11):1763-8.

6 Parkin T. Naevus sebaceous (Jadassohn) with squamous cell epithelioma. Br J Dermatol Syph. 1950 Apr;62(4):167-70.

7 Taher M, Feibleman C, Bennett R. Squamous cell carcinoma arising in a nevus sebaceous of Jadassohn in a 9 year-old girl: treatment using Mohs micrographic surgery with literature review. Dermatol Surg. 2010 Jul;36(7):1203-8.

8 Malhotra P, Arora D, Singh A. Squamous cell carcinoma, syringocystadenoma papilliferum and apocrine adenoma arising in a nevus sebaceus of Jadassohn. Indian J Pathol Microbiol. 2011 Jan-Mar;54(1):225-6.

9 Suyama T, Yokoyama M, Teraki Y, Izaki S. Case of squamous cell carcinoma arising within a linear nevus sebaceus on the trunk. J Dermatol. 2016 Oct;43(10):1236-7.

10 Jones EW, Heyl T. Naevus sebaceus. A report of 140 cases with special regard to the development of secondary malignant tumours. Br J Dermatol. 1970 Feb;82(2):99-117.

11 Ball EA, Hussain M, Moss AL. Squamous cell carcinoma and basal cell carcinoma arising in a naevus sebaceous of Jadassohn: case report and literature review. Clin Exp Dermatol. 2005 May;30(3):259-60.

12 Arshad AR, Azman WS, Kreetharan A. Solitary sebaceous nevus of Jadassohn complicated by squamous cell carcinoma and basal cell carcinoma. Head Neck. 2008 Apr;30(4):544-8.

13 Belhadjali H, Moussa A, Yahia S, Njim L, Zakhama A, Zili J. Simultaneous occurrence of two squamous cell carcinomas within a nevus sebaceous of Jadassohn in an 11-year-old girl. Pediatr Dermatol. 2009 MarApr;26(2):236-7.

14 Turan E, Buyukgural B, Ilhan Celik O. Simultaneous occurrence of two squamous cell carcinomas developing in a nevus sebaceous. Arch Iran Med. 2015 Apr;18(4):253-6.

15 Domingo J, Helwig EB. Malignant neoplasms associated with nevus sebaceus of Jadassohn. J Am Acad Dermatol. 1979 Dec;1(6):545-56.

16 Wu ZW, Shi WM, Sun Y, Li XJ, Song J. Cutaneous spindle cell squamous cell carcinoma in nevus sebaceous. Int J Dermatol. 2010 Dec;49(12):1429-31.

17 Snow JL, Zalla MJ, Roenigk RK, Gibson LE. Sudden nodular growth in a congenital facial lesion. Squamous cell carcinoma arising in a nevus sebaceus Jadassohn (NSJ). Arch Dermatol. 1995 Sep;131(9):1069, 1072. 


\section{Case Reports in Dermatology}

\begin{tabular}{l|l} 
Case Rep Dermatol 2021;13:75-82 \\
\hline DOI: 10.1159/000511692 & $\begin{array}{l}\text { @ 2021 The Author(s). Published by S. Karger AG, Basel } \\
\text { www.karger.com/cde }\end{array}$ \\
\hline
\end{tabular}

Achavanuntakul and Thanomkitti: Squamous Cell Carcinoma within a Congenital Nevus Sebaceous: Case Report and Literature Review

18 Hidvegi NC, Kangesu L, Wolfe KQ. Squamous cell carcinoma complicating naevus sebaceous of Jadassohn in a child. Br J Plast Surg. 2003 Jan;56(1):50-2.

19 Duncan A, Wilson N, Leonard N. Squamous cell carcinoma developing in a naevus sebaceous of Jadassohn. Am J Dermatopathol. 2008 Jun;30(3):269-70.

20 Alhumidi A. Acantholytic squamous cell carcinoma arising in a nevus sebaceous: A case report. Int J Health Sci (Qassim). 2013 Nov;7(3):343-6.

21 Locke ST, Schaffenburg WC, Breedlove JP, Davis Ii DW, Bowden Iii LP, Royer MC. Squamous cell carcinoma with perineural involvement in nevus sebaceus. Cutis. 2019 Apr;103(4):E17-9.

22 Hajar T, Heath M, Mengden S, Leitenberger S. Squamous cell carcinoma arising from a nevus sebaceous in an 11-year-old patient. Dermatol Surg. 2020 Jul;46(7):969-70.

23 Ashinoff R. Linear nevus sebaceus of Jadassohn treated with the carbon dioxide laser. Pediatr Dermatol. 1993 Jun;10(2):189-91.

24 Beer GM, Widder W, Cierpka K, Kompatscher P, Meyer VE. Malignant tumors associated with nevus sebaceous: therapeutic consequences. Aesthetic Plast Surg. 1999 May-Jun;23(3):224-7.

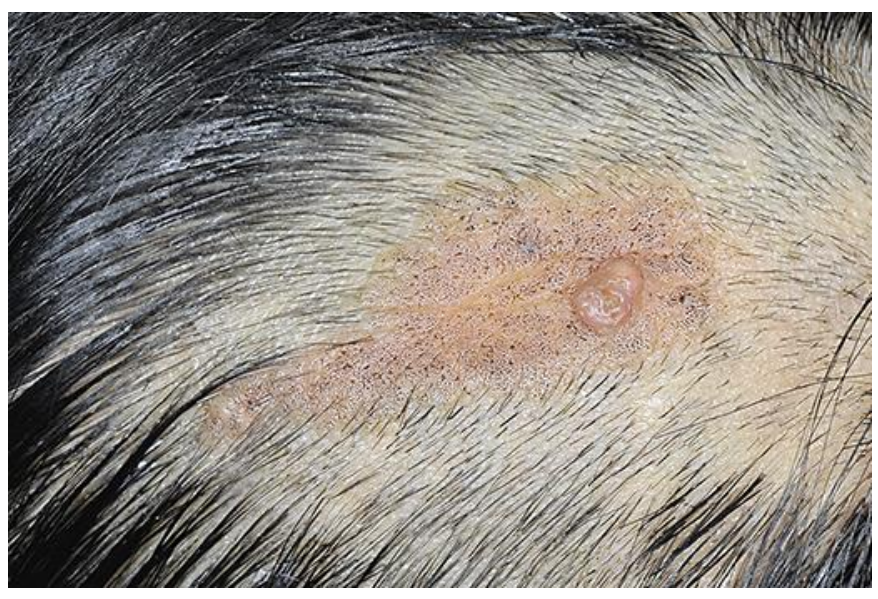

Fig. 1. A solitary erythematous papule, size $0.3 \mathrm{~cm}$ in diameter, within a well-defined, hairless verrucous, yellowish plaque, size $1.5 \times 3 \mathrm{~cm}$, on the left parietal area of the scalp. 


\section{Case Reports in Dermatology}
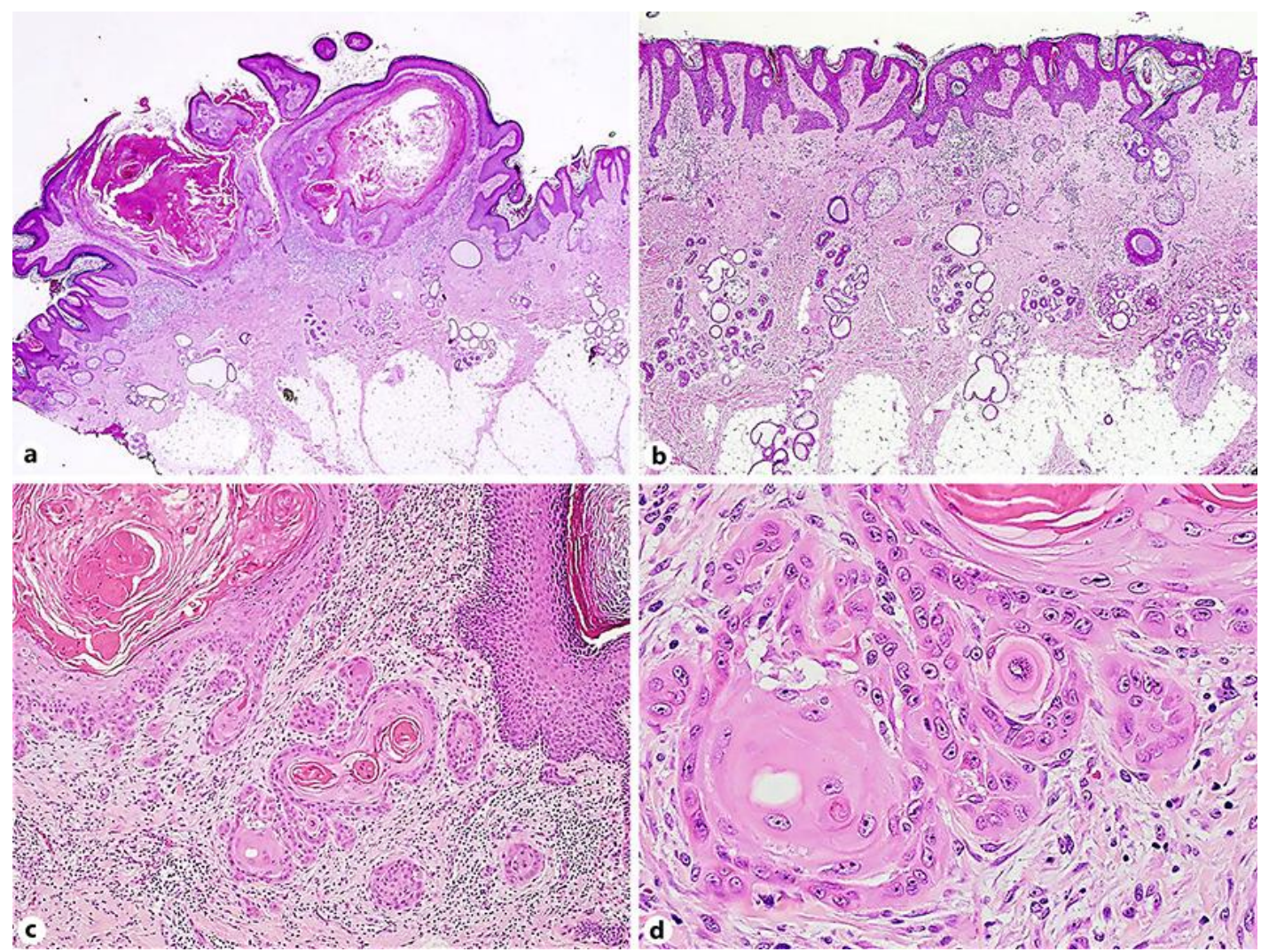

Fig. 2. Histopathologic findings demonstrate squamous cell carcinoma arising in the nevus sebaceous. a Focally keratinizing, atypical, squamous epithelial cells arising from the epidermis and extending into the dermis (H\&E stain; original magnification, $2 \times$ ). $\mathbf{b}$ The adjacent skin showed acanthosis and papillomatosis, with an abnormal location of sebaceous glands which opened directly to the skin surface, along with many ectopic apocrine glands associated with lacking anagen hair (H\&E stain; original magnification, $4 \times$ ). c Horn pearls and individual cell keratinization (H\&E stain; original magnification, 10x). $\mathbf{d}$ Large eosinophilic tumor cells with focally glassy cytoplasm and vesicular nuclei (H\&E stain; original magnification, $40 \times$ ). 
Table 1. Characteristics of the reported cases of squamous cell carcinoma arising in nevus sebaceous

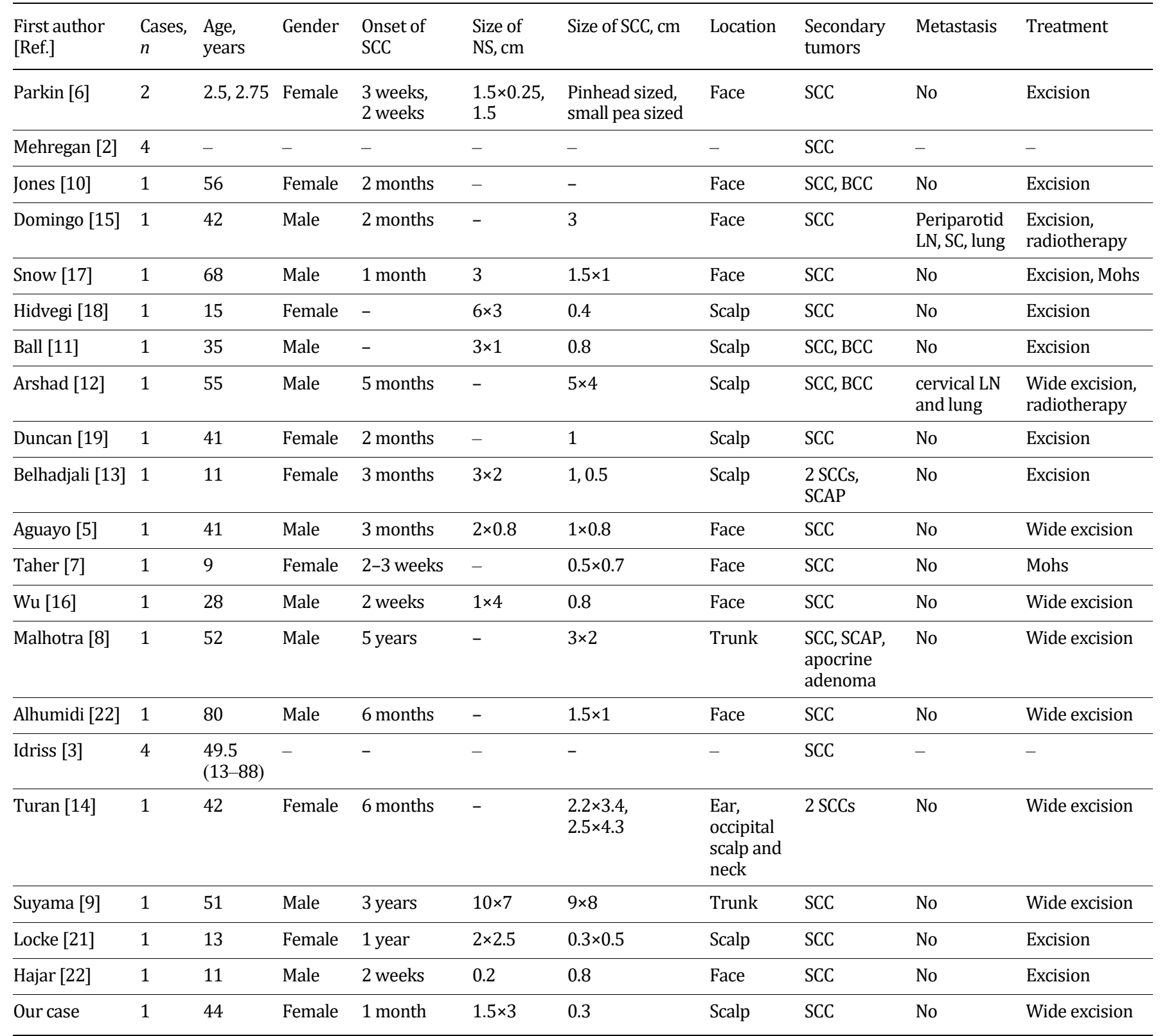

NS, nevus sebaceous; SCC, squamous cell carcinoma; BCC, basal cell carcinoma; SCAP, syringocystadenoma papilliferum; LN, lymph node; SC, subcutaneous tissue; Mohs, Mohs micrographic surgery. 